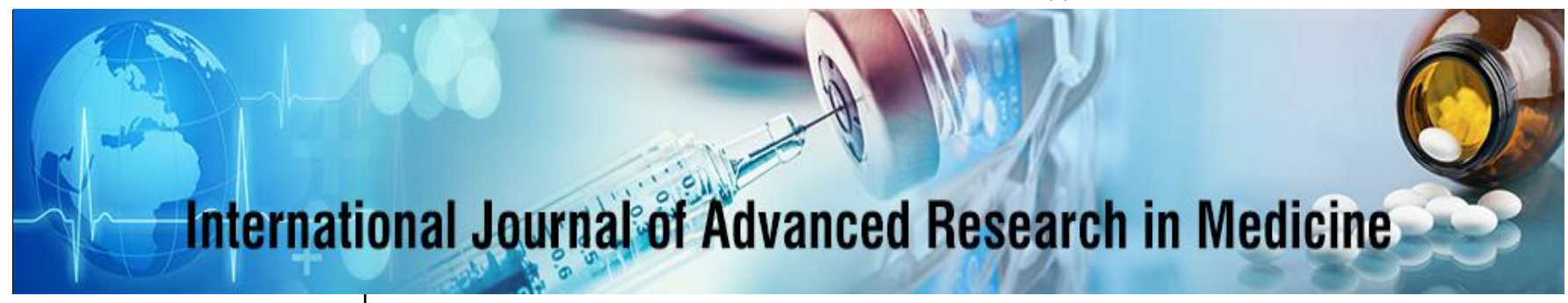

E-ISSN: 2706-9575

P-ISSN: 2706-9567

IJARM 2021; 3(1): 137-139

Received: 21-11-2020

Accepted: 25-12-2020

Dr. Sheik K Zaheer Ahamed Assistant Professor,

Department of Paediatrics,

Kanachur Institute of Medical

Sciences, Mangalore,

Karnataka, India

Dr. Adrama

Assistant Professor,

Department of Paediatrics,

Kanachur Institute of Medical

Sciences, Mangalore,

Karnataka, India
Corresponding Author:

Dr. Adrama

Assistant Professor,

Department of Paediatrics,

Kanachur Institute of Medical

Sciences, Mangalore,

Karnataka, India

\section{A Study of blood group protection to severe malarial complication in children}

\author{
Dr. Sheik K Zaheer Ahamed and Dr. Adrama
}

DOI: $\underline{\text { https://doi.org/10.22271/27069567.2021.v3.i1c.115 }}$

\begin{abstract}
Several studies undertaken have been unable to link $\mathrm{ABO}$ blood groups to the incidence of malaria and related clinical outcome. There is a paucity of hospital based, comparative studies to investigate the relationship between blood groups types and severity of malarial infections. Several studies undertaken have been unable to link ABO blood groups to the incidence of malaria and related clinical outcome. There is a paucity of hospital based, comparative studies to investigate the relationship between blood groups types and severity of malarial infections.
\end{abstract}

Keywords: Blood group, Protection, Malaria

\section{Introduction}

Several studies undertaken have been unable to link ABO blood groups to the incidence of malaria and related clinical outcome ${ }^{[2-3]}$. There is a paucity of hospital based, comparative studies to investigate the relationship between blood groups types and severity of malarial infections.

The resurgence of malaria is a serious public health problem in many parts of the world. It is therefore, important to identify the factors which contribute to susceptibility of hosts. Blood group ' $A$ ' patient was found to be more common in malaria cases than in individuals with group ' $\mathrm{O}$ ' ${ }^{[1]}$. Plasmodium falciparum rosetting, a parasite virulence phenotype associated with severe malaria, is reduced in blood group $\mathrm{O}$ erythrocyte compared with groups $\mathrm{A}, \mathrm{B}$ and $\mathrm{AB}{ }^{[4]}$. Both $\mathrm{P}$. falciparum and P. Vivax ${ }^{[15]}$ infections provides supporting evidence in favor of an effect of $\mathrm{ABO}$ group on disease severity as $\mathrm{O}$ group provides advantage over non $\mathrm{O}$ groups ${ }^{[5]}$. Individuals of blood group $\mathrm{A}$ and $\mathrm{B}$ are more susceptible to severe malaria infection as compared with individuals of blood group $\mathrm{O}$; however the severity of infection differs due to differential host susceptibility ${ }^{[6]}$. In view of the above we conducted a study to determine if any particular blood group confers some degree of protection against severe malarial complication.

\section{Aim}

- To find if any particular blood group confers some degree of protection to severe malarial complication.

\section{Materials and Methods}

The study was a prospective study conducted on 100 consenting patients presenting with smear positive malaria admitted in the Department of Pediatrics at Kanachur Institute of Medical Sciences, Mangalore from Feb 2018 to July 2020.

- Diagnosis was based on peripheral smear

- Blood group was determined by forward and reverse method

\section{Inclusion Criteria}

Smear positive malaria cases in pediatric cases.

\section{Exclusion Criteria}

$>18$ years

The clinical course between the different groups were compared using the following parameters for severe infection [WHO criteria for severe malaria] ${ }^{[8]}$. 


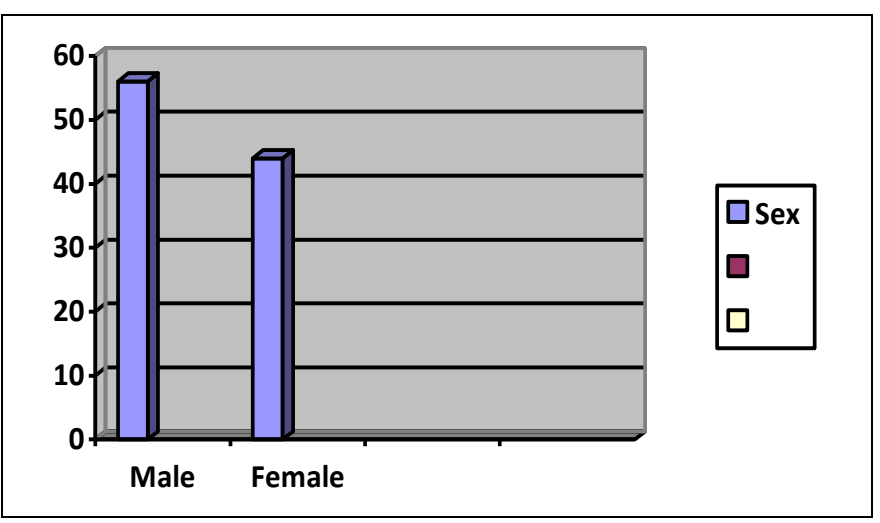

Fig 1: Sex distribution

Table 2: Blood groups association and malaria

\begin{tabular}{|c|c|c|c|}
\hline & Malaria Parasite & & \\
\hline & Falciparum & Mixed & Vivax \\
\hline $\mathrm{A}+\mathrm{ve}$ & 26 & 57.1 & 56.8 \\
\hline $\mathrm{AB}+\mathrm{ve}$ & 11 & 0.0 & 5.3 \\
\hline $\mathrm{AB}-\mathrm{ve}$ & 1 & 0.0 & 0.0 \\
\hline $\mathrm{A}-\mathrm{ve}$ & 0.0 & 0.0 & 1 \\
\hline $\mathrm{B}+\mathrm{ve}$ & 19 & 15.7 & 15.4 \\
\hline $\mathrm{B}-\mathrm{ve}$ & 1.1 & 0.0 & 0.0 \\
\hline O+ve & 36.8 & 27.2 & 19.2 \\
\hline O-ve & 5.1 & 0.0 & 2.4 \\
\hline Total & 100 & 100 & 100 \\
\hline
\end{tabular}

Table 2: Blood groups association and malarial complication

\begin{tabular}{|c|c|c|}
\hline & Malaria Parasite & \\
\hline & Complicated & Uncomplicated \\
\hline $\mathrm{A}+\mathrm{ve}$ & 34.0 & 50.0 \\
\hline $\mathrm{AB}+\mathrm{ve}$ & 0.0 & 8 \\
\hline $\mathrm{AB}-\mathrm{ve}$ & 0.0 & 0.7 \\
\hline $\mathrm{A}-\mathrm{ve}$ & 0.0 & 0.8 \\
\hline $\mathrm{B}+\mathrm{ve}$ & 28.5 & 13.6 \\
\hline $\mathrm{B}-\mathrm{ve}$ & 0.0 & 0.8 \\
\hline O+ve & 34.0 & 23 \\
\hline O-ve & 1.5 & 3 \\
\hline Total & 100 & 100 \\
\hline
\end{tabular}

\section{Discussion}

It is a well known fact that blood groups are an expression of genetic constitution; in view of this statement we conducted a study to find the influence of blood groups on susceptibility to malaria ${ }^{[7-8]}$. Malaria has been emerging as a major national health problem with considerable morbidity and mortality and has long been eluding our efforts for an effective control ${ }^{[13-15]}$.

Aditya K Panda et al. ${ }^{[9]}$, Zerihun, Tewodro et al. ${ }^{[10]}$ in different studies showed that a higher percentage of males than females were affected by malaria which is comparable with the results of our study

Tauseef Ahmad et al. [11] in their study has a higher percentage of males $58.7 \%$ than females $41.3 \%$ which is comparable with the results of our study.

Jimmy Antony et al. ${ }^{[12]}$ studied 139, out of which 121 cases were males $(87.05 \%)$ and 18 cases $(12.95 \%)$ were females, which is comparable with the results of our study.

These results are different as compared to the study by Tyagi S.P [16] who found blood group B to be the predominant blood group $(37.21 \%)$ in his study of the distribution of blood groups in Uttar Pradesh.

In a study involving 170 children, Tejinder Singh ${ }^{[17]}$ found a preponderence of P. Falciparum ${ }^{[4]}$ infection. Incidence of malaria was found to be maximum in those with blood group A, A/0 ratio being 1.93 .

Singh, Shukla et $a l^{[18]}$ in their study involving ABO groups among malaria cases from district Mandla, Madhya Pradesh found that blood groups $\mathrm{A}, \mathrm{B} \& \mathrm{O}$ were equally susceptible to malaria infection but $\mathrm{AB}$ group had less number of persons with malarial parasites. A lower frequency of $\mathrm{P}$. falciparum was observed among individuals with blood groups A and 0.

Fischer PR. and Boone P. ${ }^{[19]}$ studied 489 patients in Zimbabwe in an effort to see if clinically severe malaria was associated with blood group. They found that patients with malaria and blood group A had lower haemoglobin levels and more risk of coma than did infected patients with other blood groups, similar findings were noted in our study

Aditya K Panda et al. ${ }^{[9]}$ showed in their study that the blood group 'B' was significantly higher in patients with severe malaria, whereas in our study it was group ' $\mathrm{A}$ ' was more common.

Higher prevalence of blood group 'O' was observed in uncomplicated cases in various studies by Rowe et al. ${ }^{[20]}$, Lell et al. ${ }^{[21]}$ and Zerihun et al. ${ }^{[7]}$, similar findings were noted in our study.

\section{Conclusion}

The severity and complications are more in patients with blood group $\mathrm{O}$.

\section{References}

1. Bulletin of the WHO 1980;58(6):913-915.

2. Facer CA, Brown J. ABO blood groups and falciparum malaria. Trans R Soc Trop Med Hyg 1979;73:599-600.

3. Singh N, Shukla MM, Uniyal VP, Sharma VP. ABO blood groups among malaria cases from district Mandla, Madhya Pradesh. Indian $\mathbf{J}$ Malarial 1995;32:59-63.

4. Rowe A, Obeiro J, Newbold CI, Arsh K. Plasmodium Falciparum values roseting is associated with malaria severity in Kenys. Infect Immun 1995;89(6):635-7.

5. Deepa, Alwar VA, Rameshkumar K, Ross C. ABO blood groups and malaria related Clinical outcome. J Vector Borne Dis 2011;48:7-11.

6. Gayathri BN, Kumar HML, Gomathi N, Shetty J, Reethesh RP. Relationship between ABO blood groups and malaria with clinical outcome in rural area of South India. GJMEDPH 2013;2(1).

7. Hay SI, Guerra CA, Tatem AJ, Noor AM, Snow RW. The global distribution and population at risk of malaria: past, present, and future. The Lancet infectious diseases (2004):4(6)327-336.

8. Morrow RH, Moss WJ. The epidemiology and control of malaria. Infectious disease epidemiology: theory and practice. Gaithersburg, MD: Aspen Publishers 2001, 675-710.

9. Panda AK, Panda SK, Sahu AN, Tripathy R, Ravindran $\mathrm{B}$ et al. Association of $\mathrm{ABO}$ blood group with severe falciparum malaria in adults: case control study and meta-analysis. Malar J 10 2011, 309.

10. Zerihun T, Degarege A, Erko B. Association of ABO blood group and Plasmodium falciparum malaria in Dore Bafeno Area, southern Ethiopia. Asian Pacific J Trop Biomed 2011;1:28994.

11. Ahmad, T. Occurrence of Malaria In Khwazakhela 
District Swat Pakistan. 2013.

12. Antony J, Celine TM, Chacko M. Staging back of Malaria in Kerala, India: A Retrospective study. International Research Journal of Social Sciences 2013;2(12):42-46.

13. Dondorp AM, Nosten F, Yi P, Das D, Phyo AP, Tarning $\mathbf{J}$ et al. "Artemisinin resistance in Plasmodium falciparum malaria." New England Journal of Medicine 2009;361(5):455-467.

14. Gupta M, Chowdhuri ANR. Relationship between ABO bloods groups and malaria. Bull. WHO. 1980;58:913915.

15. Zakeri S, Kakar Q, Ghasemi F, Raeisi A, Butt W, Safi $\mathrm{N}$ et al. "Detection of mixed Plasmodium falciparum \& P. vivax infections by nested-PCR in Pakistan, Iran \& Afghanistan. 2010.

16. Tyagi SP. Distribution of ABO blood groups in Uttar Pradesh. Journal of the Indian Medical Association. 1968;51(2):57-59.

17. Singh T. Malaria and ABO blood groups. Indian Pediatr 1985;22(11):857-8.

18. Singh N, Shukla MM, Uniyal VP, Sharma VP. ABO blood groups among malaria cases from district Mandla, Madhya Pradesh, Indian J. Malarial 1995;32 (2):59-63.

19. Fischer PR, Boone P. Short report: Severe malaria associated with blood group. Am J Trop Med Hyg 1998;58:122-3.

20. Rowe A, Obeiro J, Newbold CI and Marsh K. Plasmodium Falciparum rosetting is associated with malaria severity in Kenya. Infect. Immun 1995;63: 2323-2326.

21. Lell B, May J, Schmidt Ott R, Lehman L, Luckner B, Greve $\mathrm{B}$ et al. The role of red blood cell polymorphisms in resistance and susceptibility to malaria. Clin. Infect Dis 1999;28:794-799. 